Edukacja Filozoficzna 69/2020

ISSN 0860-3839

DOI: $10.14394 /$ edufil.2020.0009

ORCID: 0000-0002-4166-1388

\title{
Antropologia filozoficzna Bogusława Wolniewicza
}

\author{
Jan Zubelewicz \\ (Politechnika Warszawska, Wydział Administracji i Nauk Społecznych)
}

\section{Wprowadzenie}

Antropologia filozoficzna, czyli opis natury ludzkiej, jest podstawą dla tworzenia aksjologii, politologii, teologii, prakseologii. Ludzie posiadają różne przekonania o naturze ludzkiej, czyli ich antropologie filozoficzne są spersonalizowane. Jeżeli przekonania są różne i się wykluczają, to przynajmniej niektóre muszą być fałszywe. Jeżeli więc te założenia są fałszywe, to wyprowadzone $\mathrm{z}$ nich logiczne konsekwencje też mogą być fałszywe. Które przekonania są prawdziwe, a które fałszywe? Odpowiedź jest niezwykle trudna, bo badacze też mają swoje przekonania, które w ich odczuciu są prawdziwe, a faktycznie może być różnie: mogą być prawdziwe lub fałszywe. Powstaje błędne koło. Kręcimy się wokół własnego ogona, a nie wokół prawdy. Może by znaleźć taką osobę (bądź takie osoby), której antropologia filozoficzna byłaby pewnego rodzaju wzorcem. Ale wówczas ukazana trudność przesuwa się tylko na inne pole. Kto jest taką osobą? Dla mnie takim punktem odniesienia jest Bogusław Wolniewicz (1927-2017) i jego antropologia filozoficzna.

Artykuł składa się z czterech części: wstępnej: opisującej Wolniewicza rozumienie nauki, głównej: przedstawiającej jego rozumienie antropologii filozoficznej oraz moich uwag i zakończenia. Główne tezy są ponumerowane.

Bardzo dziękuję Kamilowi Zubelewiczowi za różne uwagi związane z poniższym tekstem. 


\section{O nauce}

Prawda to wartość naczelna nauki. Badacze mają na celu dochodzenie i odkrywanie zdań prawdziwych. Aby to zadanie zrealizować, muszą zaistnieć, według Wolniewicza, pewne warunki intelektualne i społeczne. Wskazuje on na dwie wartości podnaczelne w procesie dochodzenia do prawdy: jasność myśli i swobodę krytyki². Obie mogą być społecznie i politycznie kwestionowane. Warunkiem jasności myśli jest jej niesprzeczność, ład pojęciowy, definiowanie, warunkiem swobody krytyki zaś - istnienie odpowiednich warunków społeczno-politycznych. Jak pisał Wolniewicz:

[...] nauka jest dziełem ludzkim, a stawia sobie cele ponad-ludzkie. Aby ją tworzyć, ludzie muszą niejako wychodzić z siebie, ponad swe ułomne umysły i jeszcze ułomniejsze charaktery. Niezbędny więc jest jakiś mechanizm społeczny, który by ich stale i skutecznie do tego morderczego wysiłku zmuszał, zaś owe ułomności - neutralizował. Mechanizmem tym jest właśnie swobodna krytyka i wolna konkurencja poglądów - równie swobodna i bezwzględna, jak konkurencja w sporcie wyczynowym, gdzie ludzie też widzą się stale zmuszeni wykraczać poza to, co zdaje się już kresem ludzkich możliwości. Na terenie nauki nie ma w szczególności żadnego zastosowania tak ulubione przez wielu pojęcie „krytyki konstruktywnej” (czyli w praktyce takiej, która nie zagraża pozycji krytykowanego) ${ }^{3}$.

Mamy więc pierwszą tezę Wolniewicza:

(1) Prawda jest wartością naczelną nauki. Wartościami podnaczelnymi są: jasność myśli i swoboda krytyki

Można wyróżnić nauki ścisłe (o przyrodzie, o przyrodniczym aspekcie człowieka i o wytworach człowieka) i nauki społeczne (o społeczno-duchowym aspekcie człowieka), czy też może należałoby powiedzieć: tzw. nauki społeczne. Do nauk ścisłych zalicza Wolniewicz matematykę, fizykę, chemię i biologię oraz nadbudowane nad nimi nauki przyrodnicze, nauki rolnicze, nauki medyczne, na-

2 B. Wolniewicz, Naczelne wartości naukowego poglądu na świat [1980], w: tegoż, Filozofia i wartości. Rozprawy i wypowiedzi, WFiS UW, Warszawa 1993, s. 65.

3 Tamże, s. 67.

4 Tamże, s. 62-68. 
uki weterynaryjne i nauki techniczne. Różnicę między wymienionymi grupami nauk charakteryzują dwie tezy:

(2) Aksjomatyka nauk ścisłych jest oczywista i akceptowana przez badaczy.

(3) Trwa ciągły spór o aksjomatykę nauk społecznych.

Dlaczego taki spór ciągle trwa? Wolniewicz chyba wprost na to nie odpowiada. Ale w duchu jego filozofii można by chyba wskazać na dwie przyczyny: różne nasze uwarunkowania antropologiczne i polityczno-społeczne. Jeżeli udałoby się nam powiedzieć coś prawdziwego o naturze ludzkiej, to byłby to krok naprzód w rozwoju nauk społecznych.

\section{Antropologia filozoficzna}

Wolniewicz przyjmuje, że coś takiego jak natura ludzka istnieje. Jeżeli kwestionuje się istnienie natury ludzkiej, jak np. w przypadku Richarda Rorty'ego ${ }^{5}$, to również jest to pewne przekonanie antropologiczne. Poniżej wymieniam niektóre tezy antropologii filozoficznej Wolniewicza. Rozpoczynam od najważniejszej - od radykalnego natywizmu.

\section{Natywizm radykalny}

(4) Człowiek zaczyna się w chwili poczęcia, czyli od powstania zygoty. W tym momencie powstają in potentia wszystkie jego główne cechy, te, które go determinują i określają jego tożsamość.

W momencie poczęcia, czyli w chwili wielkiego wybuchu, dwie komórki rozrodcze (gamety) - ojcowski plemnik i macierzyńskie jajo - łączą się w jedną zygotę. Poszczególne gamety mają po 23 chromosomy, w zygocie (komórce diploidalnej) znajduje się 46 chromosomów. Przyjęcie każdego innego momentu rozpoczęcia życia byłoby rozwiązaniem arbitralnym. Wolniewicz uważa, że w chwili poczęcia zostają ustalone m.in. następujące cechy: ekspansja życiowa i sprzężona $\mathrm{z}$ nią dynamika, charakter, inteligencja, temperament, sumienie, religijne poruszenie

Z. Musiał, B. Wolniewicz, Wstęp, w: tychże, Ksenofobia i wspólnota. Przyczynek do filozofii człowieka, wyd. 2 poszerzone, Wyd. Antyk - Marcin Dybowski, Komorów 2010, s. 7. 
duszy, język, wspólnotowość, słuch muzyczny, płeć, grupa krwi, prawo- lub leworęczność, różne cechy fizyczne (np. wzrost, kolor oczu, kolor włosów, uroda) ${ }^{6}$. Od siebie dodaję jeszcze np. pamięć czy różne ograniczenia zdrowotne. Przyjmijmy umownie, że wymienione cechy określają natywizm umiarkowany. Wolniewicz przyjmuje jeszcze coś więcej, coś bardziej radykalnego. Uważa, że podczas poczęcia określone są percepcje niektórych cech natury ludzkiej. Te percepcje nie są poglądami, a rysami czy typami osobowości w sferze poznawczej. Ostatnie wyróżniki przemawiają za radykalnym natywizmem Wolniewicza.

To całe wyposażenie określa indywidualność człowieka.

Jesteśmy - pisze Wolniewicz - niczym maszynista: jedzie po torach nie przez siebie ułożonych i w nie przez siebie wyznaczonym kierunku. Może jechać lub stanąć, przyspieszyć lub zwolnić, w przód lub w tył; na kierunek jazdy wpływu nie ma żadnego ${ }^{7}$.

W chwili zapłodnienia tor życiowego rozwoju zarodka został już tak samo jednoznacznie określony jak tor rakiety kosmicznej w chwili jej odpalenia ${ }^{8}$.

Z danym człowiekiem wiąże się jego ekspansja życiowa: jego siły biologiczne i społeczne. W chwili poczęcia dynamika tej ekspansji jest największa, potem ta dynamika cały czas maleje ${ }^{9}$.

Dopełnieniem natywizmu jest antynatywizm ${ }^{10}$.

\section{Nonmelioryzm natury ludzkiej}

(5) Natura ludzka w aspekcie moralnym jest układem trzech sił: zwierzęcej interesowności, ludzkiej szlachetności i ludzkiej nikczemności (nonmelioryzm) $)^{11}$.

$6 \quad$ B. Wolniewicz, O tzw. bioetyce [2001], w: tegoż, Filozofia i wartości, t. III, WFiS UW, Warszawa 2003, s. 153 oraz B. Wolniewicz, O idei losu [2010], w: tegoż, Filozofia i wartości, t. IV, Wyd. UW, Warszawa 2016, s. 254.

7 Z. Musiał, B. Wolniewicz, Wstęp, w: tychże, Ksenofobia i wspólnota, dz. cyt., s. 9.

8 B. Wolniewicz, O tzw. bioetyce, dz. cyt., s. 153.

9 B. Wolniewicz, Wykład o krzywej życia, w: tegoż, W stronę rozumu, kompozycja tekstu J. Faliński, D. Dywańska, WEMA, Warszawa 2015, s. 140-145.

10 Terminu takiego używa Jędrzej Stanisławek, Podstawy filozofii (ujęcie teoretyczne), Drukarnia Oficyny Wydawniczej Politechniki Warszawskiej, Warszawa 2015, s. 85-86.

11 B. Wolniewicz, Melioryzm Leibniza, „Przegląd Filozoficzny - Nowa Seria” 2016, nr 4(100), s. $293-294$. 
Układ ten w różnych proporcjach występuje u ludzi i wyraża się w różnorodności ludzkich charakterów. Powyższe stanowisko określa Wolniewicz jako nonmelioryzm. Ludzka nikczemność przejawia się w złej radości (radość z cudzego nieszczęścia) i nikczemnym smutku (smutek z cudzego szczęścia). Jedno i drugie przejawia się zupełnie bezinteresownie ${ }^{12}$. Melioryści uważają, że natura ludzka w aspekcie moralnym to układ tylko dwu sił: życiowego interesu (siły biotyczne, zwierzęca interesowność) i ludzkiej szlachetności (siły dobrej woli, siły pokoju). Przyjmują oni aksjomat Jana Jakuba Rousseau (1712-1778): człowiek z natury jest dobry. Stale dąży ku lepszemu. Jeżeli czyni zło, to płynie ono spoza niego, spoza jego natury ${ }^{13}$. Dobra dusza człowieka ulega złym, zewnętrznym wobec niej, wpływom i w rezultacie pojawia się zła wola i złe czyny. Melioryzm stara się jakoś usprawiedliwić to zło. Do tego potrzebna jest odpowiednia antropodycea. Wolniewicz dostrzega w niej trzy drogi. Pierwsza wiąże zło z błędem rozumu: „zło jest błędem rozumu, a nie skazą woli”. Gdyby człowiek wiedział, to nie czyniłby zła. Tym tropem podążał Sokrates (470-399 p.n.e.). Druga - ze złym systemem społecznym: „zło jest błędem systemu społecznego zwróconego przeciwko człowiekowi”. Gdyby instytucje społeczne były dobre, to człowiek nie czyniłby zła. Tą drogą poszedł Rousseau. Trzecia - z materią i ciałem: „zło płynie z materii albo ciała, a nie z ducha czy duszy". Do takiego rozwiązania skłaniał się Zygmunt Freud (1856-1939), według którego w niewinnym ego rodzą się różne patologie, bo mieści się ono między ślepym id i opresyjnym super-ego. W pierwszym przypadku grzech jest błędem rozumu, w drugim - błędem systemu społecznego, $\mathrm{w}$ trzecim - rodzajem choroby ${ }^{14}$.

Wolniewicz zastanawia się nad tym, dlaczego Leibniz (1646-1716) wyznawał fałszywą teorię poznania, jaką jest melioryzm. Dodajmy, że był to melioryzm w pewnej odmianie wersji intelektualistycznej. Pierwszy trop, który się tutaj nasuwa: Leibniz zwiastował myśli Oświecenia i szedł z duchem swojego czasu. A w Oświeceniu, jak wiadomo, wyznawano aksjomat o dobroci człowieka. Takie wyjaśnienie, w odniesieniu do tak wybitnego myśliciela, nie zadowala Wolniewicza. Idzie on innym tropem - genetycznym. To genetyczne uwarunkowania sprawiły, że Leibniz był zakodowany na meliorystyczne widzenie natury ludzkiej. Melioryzm nie jest poglądem, tylko rysem osobowości człowieka, głęboko

Tamże, p. 4: Zła radość, s. 296-297.

Tamże, s. 298.

14 Tamże, s. 298. Jest w artykule punkt pt. Drogi antropodycei. 
ugruntowanym genetycznie. Potem ten rys osobowości znajduje odzwierciedlenie w widzeniu natury ludzkiej. Przytoczmy w tej sprawie znaczący fragment analiz Wolniewicza.

Jak umysł jego [Leibniza] miary mógł tego [błędu] nie widzieć? [...]

W przypadku umysłu tej miary, wyjaśnienie historyczne zdaje się niewystarczające, i to grubo. Opowiadamy się za innym - genetycznym.

Melioryzm jest wiarą; ale zarazem jest czymś w rodzaju daltonizmu: przyrodzoną wadą w percepcji pewnych zjawisk. Daltonizm jest, jak wiadomo, wrodzoną i niekorygowalną wadą wzroku, która polega na nieodróżnianiu pewnych kolorów; typowo czerwieni i zieleni. Podobnie melioryzm byłby wrodzoną i niekorygowalną wadą w percepcji natury ludzkiej, polegającej na nieodróżnianiu złośliwości od głupoty; a przynajmniej na ich odróżnianiu mało wyraźnym.

Leibniz był dotknięty meliorystyczną wadą percepcji - tak brzmi nasza diagnoza jego przypadku. Na tę wadę, jako konstytucyjną, nie pomoże nawet geniusz.

Melioryzm to nie jest pogląd; to jest rys osobowości, wyryty głęboko w materiale genetycznym. Meliorystą człowiek się nie staje, tylko rodzi. Potem znajduje to wyraz między innymi w tym, co skłonny jest sądzić o naturze ludz$\mathrm{kiej}^{15}$.

Przekonania meliorystów są bardzo rozpowszechnione oraz mają przepotężny i zgubny wpływ w pedagogice ${ }^{16}$, psychologii, politologii, kryminalistyce czy teologii.

\section{Sumienie}

Wolniewicz przyjmuje - za słownikiem Webstera - następującą definicję sumienia: to „rozpoznanie lub wyczucie tego, co dobre i złe, wraz z przynagleniem

\footnotetext{
Tamże, s. 300 .

16 Zob. np. J. Zubelewicz, Przyczyny przemocy uczniów wobec nauczycieli. Pedagogika akademicka a pedagogika Johanna F. Herbarta i Bogusława Wolniewicza, w: Wychowanie i kształcenie w systemach politycznych, red. E. Anhalt, D. Stępkowski, Wydawnictwo Salezjańskie, WNP UKSW, Warszawa 2012, s. 185-211.
} 
wewnętrznym, by iść za dobrem"17. Mamy tutaj dwie składowe: intelektualną („rozpoznanie lub wyczucie”) oraz emocjonalną („przynaglenie wewnętrzne”). Pierwsza składowa jest bierna, druga - czynna. Sumienie bierne można też nazwać „prasumieniem”, „synderezą” czy „rozumem praktycznym”. Sumienie bierne cechuje się zdolnością do odróżniania dobra od zła. Ta zdolność w odniesieniu do sytuacji zewnętrznej nazywana jest „apercepcją moralną”. Uczestniczy w niej coś spoza porządku przyrodniczego. Odzywa się w człowieku ,jakiś głos wieszczy”, pewna powinność bytu: coś, co powinno być. To odezwanie się - uważa Wolniewicz - ma charakter egalitarny: odzywa się w każdym człowieku. Sumienie bierne posiada więc każdy człowiek. Inaczej z sumieniem czynnym: nie wszyscy je posiadają. Są ludzie, którzy nie realizują postulatów sumienia biernego: wiedzą, co dobre, ale tego nie czynią. Wprost przeciwnie, mogą wiedzieć, że coś jest złe, i świadomie to czynić. Mamy wtedy do czynienia z działaniem diabelskim. Ma to miejsce w przypadku charakterów złych ${ }^{18}$. Wniosek końcowy brzmi następująco:

(6) Każdy człowiek posiada sumienie bierne (zdolność odróżniania dobra od zła), nie każdy posiada sumienie czynne (nie u każdego człowieka istnieje wewnętrzne przynaglenie, by iść za dobrem).

\section{Tychizm}

(7) Człowiek nie jest kowalem, a jest tragarzem swojego losu (tychizm) ${ }^{19}$.

W odniesieniu do losu są dwa stanowiska: tychizm (człowiek jest tragarzem swojego losu) i antropizm (człowiek jest kowalem swojego losu). Wolniewicz uważa, że los to wypadkowa przeznaczenia i przypadku. Przeznaczenie wyznaczają trzy czynniki, które wcześniej zaistniały, wywierały i wywierają wpływ na nas. Są to: nasz genotyp: jacy wcześniej się poczęliśmy, nasza epoka: kiedy się urodziliśmy, i nasza wspólnota plemienna: wśród jakich ludzi się urodziliśmy ${ }^{20}$. Na te trzy czynniki nie mamy żadnego wpływu. Najważniejszy jest ge-

\footnotetext{
17 B. Wolniewicz, Hedonizm i obowiązek [2006/2007], w: tegoż, Filozofia i wartości, t. IV, dz. cyt., s. 127.

18 Tamże.

19 B. Wolniewicz, O idei losu, dz. cyt., s. 250.

20 Tamże, s. 252.
} 
notyp. „Przeznaczenie - pisze Wolniewicz - nie wyklucza wolnej woli, tylko ją ogranicza"21. Trzeba jednak pamiętać, że z tychicznego punktu widzenia wolny wybór w sytuacji „rozstajnej” jest szczególnym rodzajem przypadku²2. Antropicy nie mogą pogodzić się z ograniczeniami tychizmu. Proponują różne formy „myślenia i życia pozytywnego": myślenie, że świat został specjalnie stworzony dla nas i my jesteśmy jego gospodarzami („zasada antropiczna”), osiąganie długowieczności dzięki transplantacjom i kontaktom z przyrodą (obejmowanie drzew, zakopywanie się po szyję w ziemi). Deontysta antropiczny wierzy, że świadomość obowiązku (świadomość aksjologiczna) może nas zmusić, byśmy swój obowiązek faktycznie poczuli i spełnili. Deontysta tychiczny wie, że świadomość obowiązku jest tylko warunkiem koniecznym spełnienia obowiązku. Do tego musi się jeszcze dołączyć wola (intencja aksjologiczna), by owo spełnienie nastąpiło ${ }^{23}$.

Analizowany spór między tychizmem a antropizmem można by, według mnie, zobrazować następującymi ludowymi porzekadłami. Antropicy mówią: „Jak sobie pościelesz, tak się wyśpisz”. Na to tychicy replikują: „Człowiek strzela, Pan Bóg kule nosi”. „Antropizm - pisze Wolniewicz - czyli mniemanie, że człowiek jest panem swojego losu - to wyraz rozplenionego egotyzmu i megalomanii, odbierających ludziom rozum" 24 .

Rozpowszechnione na terenie polityki i politologii tzw. myślenie doktrynerskie to rodzaj myślenia antropicznego. Doktrynerstwo polega bowiem na tym, że:

daną empirycznie rzeczywistość społeczną zestawia się nie z drugą tak samo daną, lecz z wykoncypowanym ideałem, którego urzeczywistnialność gwarantuje jedynie wiara w nieomylność własnej doktryny ${ }^{25}$.

Omawiane dwa stanowiska nie są, według Wolniewicza, poglądami, a typami osobowości. Są one ukształtowane już w zygocie. Tego zmienić już nie możemy. Możemy, co najwyżej, dany typ w sobie uświadomić:

Tamże, s. 258.

22 Tamże, s. 257-258.

23 B. Wolniewicz, Polemika Kanta $z$ hedonizmem, „Edukacja Filozoficzna” 2016, Nr specjalny, s. 91, przedruk w: tegoż, Filozofia i wartości, t. IV, dz. cyt., s. 145. Cyt. dalej wg tomu IV. Faktycznie w tekście tym występuje opozycja: deontysta racjonalistyczny - deontysta tychiczny, ale prof. Wolniewicz w 2016 zaaprobował zmianę terminu "deontyzm racjonalistyczny” na termin: „deontyzm antropiczny” (patrz: uwaga w punkcie 3.4. tego artykułu).

24 B. Wolniewicz, O idei losu, dz. cyt., s. 258.

25 B. Wolniewicz, Z pedagogiki ogólnej, w: Dydaktyka szkoły wyższej: wybrane zagadnienia, red. U. Schrade, OW PW, Warszawa 2010, s. 23. 
[...] antropizm i tychizm to nie są dwa poglądy. To są dwa typy osobowości, typ A i typ T. Mówiąc za Kantem, są to dwie przeciwne sobie zasady regulatywne naszego myślenia o życiu i świecie. Takich zasad nikt nie wybiera: przydziela je nam los - już w zygocie. Mamy je nie w głowie, lecz w trzewiach, jak grupę krwi, albo jak swą prawo- lub leworęczność. Własną zasadę regulatywną można sobie co najwyżej uświadomić; zmienić ją nie jest w naszej mocy, ani w mocy czyjejkolwiek perswazji lub argumentacji. Bo ta zasada to właśnie my, nasz $\operatorname{los}^{26}$.

Uważam, że myślenie antropiczne przejawia się w cechach języka propagandy politycznej ${ }^{27}$, w jej naczelnej cesze: magicznym pojmowaniu języka (o czym mówimy, to istnieje; o czym nie mówimy, to nie istnieje) oraz innych podrzędnych cechach. Jedna z nich, niezwykle znacząca i rozpowszechniona, to „zasada Kalego” (zasada dwóch miar w sądach wartościujących) ${ }^{28}$. Dużym powodzeniem cieszy się myślenie antropiczne w psychologii wychowawczej i psychoterapii ${ }^{29}$. Terapia psychologów o nastawieniu antropicznym może jedynie pogłębić daną patologię, dysfunkcjonalność (np. depresję, przemoc uczniów wobec nauczycieli, itd.).

\section{Woluntatyzm}

Czy wola dominuje nad rozumem, czy rozum nad wolą? Pytanie to można sprecyzować dokładniej: czy wola pobudza rozum do myślenia, czy też rozum pobudza wolę do działania? Są tutaj dwie odpowiedzi i zarazem dwa stanowiska: woluntaryzm i intelektualizm etyczny. Wolniewicz jest zwolennikiem woluntaryzmu. Używa przy tym nazwy: „woluntatyzm”. Oto jego teza:

(8) Jedyną sprężyną chceń i działań jest w człowieku wola. Dominuje ona nad rozumem: pobudza go do myślenia (woluntatyzm) ${ }^{30}$.

26 B. Wolniewicz, O idei losu, dz. cyt., s. 259.

27 J. Zubelewicz, Cechy języka propagandy realnego socjalizmu, w: Skłonność metafizyczna. Bogusławowi Wolniewiczowi w darze, red. M. Omyła, WFiS UW, Warszawa 1997, s. 373-388.

28 Tamże, s. 377-378.

29 J. Zubelewicz, Dwie filozofie edukacji: aksjocentryzm i pajdocentryzm, OW PW, Warszawa 2003, podrozdział: Ambiwalentna czy pozytywna rola psychologii wychowawczej i psychoterapii?, s. 277-288.

30 B. Wolniewicz, Aksjomat Elzenberga, „Przegląd Filozoficzny” 2017, nr 4(104), oraz tegoż, Polemika Kanta, dz. cyt., punkty 6 i 7. 
Rozum jest bierny, ślepy jest na dobro i zło, do swojego działania potrzebuje impulsu od woli. Gdy taki impuls jest, to wtedy nam coś uświadamia, ale do niczego nas nie skłania. Ewentualne działanie człowieka jest uzależnione od reakcji usposobienia (interesu własnego i charakteru) na to uświadomienie. Wolniewicz aprobuje ustalenia Davida Hume'a (1711-1776), że rozum nie stwarza impulsu do czynu, ale nim kieruje. Przytoczmy odpowiedni fragment tekstu Wolniewicza ${ }^{31}$ :

Tymczasem rozum jest jak wzrok czy słuch: coś nam jedynie uprzytamnia, do niczego nie skłania. Czy to, co zostało uprzytomnione, także nas poruszy, jest już kwestią nie rozumu, lecz usposobienia, czyli naszego interesu i naszego charakteru. Rozum to lustro, nie motor. Motory naszych działań - jak wola życia, szukanie szczęścia, dążenie do prawdy - leżą gdzie indziej.

W sytuacji rozstajnej rozum tylko rozpoznaje jej opcje: możliwości działania, jakie ona otwiera. Na jej gradient hedoniczny wpływu nie ma żadnego.

Podzielamy pogląd Hume’a, że „rozum sam nie może być nigdy motywem dla poruszenia woli”32; i że „impuls [do czynu] nie rodzi się z rozumu, lecz jest przezeń tylko kierowany"33.

Istotę tego kierownictwa odzwierciedla, według Wolniewicza, zwykły sylogizm praktyczny z operatorami modalnymi $O$ (chcemy, by...) i $L$ (wiemy, że...): "Chcemy, by było $p$; ale wiemy, że bez $q$ nie będzie $p$. Zatem chcemy także, by było $q$ ". W postaci graficznej sylogizm przyjmuje następującą postać (rys. 1) ${ }^{34}$.

Rys. 1. Motor naszego działania (wola) i jego kierownica (rozum)

\begin{tabular}{|c|c|c|c|}
\hline$O p$ & chcemy, by było $p$ & motor naszego działania & (przesłanka mniejsza) \\
\hline$L(\neg q \Rightarrow \neg p)$ & ale wiemy, że bez $q$ nie będzie $p$ & kierownica działania & (przesłanka większa) \\
\hline$\overline{O q}$ & Zatem chcemy także, by było $q$ & motor i kierownica & (wniosek) \\
\hline
\end{tabular}

Źródło: Oprac. B. Wolniewicz, Polemika Kanta z hedonizmem [2016], w: tegoż, Filozofia $i$ wartości, t. IV, Wyd. UW, Warszawa 2016, s. 145 (kolumna pierwsza) oraz oprac. własne (kolumny dalsze) na podstawie ww. tekstu.

31 B. Wolniewicz, Polemika Kanta, dz. cyt., s. 144.

32 Zob. D. Hume, A Treatise of Human Nature, edited with an analytical index, by L.A. Selby-Bigge, Oxford 1869, s. 413.

33 Tamże, s. 414.

34 B. Wolniewicz, Polemika Kanta, dz. cyt., s. 144-145. 
Mamy kolejną tezę:

(9) W impulsach pierwotnych naszego działania rozum nie odgrywa żadnej roli, we wtórnych - ma sterowniczy swój udział, jak w sylogizmie (rys. 1).

Tego właśnie dotyczy spór między Elzenbergiem a Miłoszem i Conradem ${ }^{35}$.

Ogół naszych skłonności i dążności pierwszych nazywa Wolniewicz wolą. A co kieruje wolą? Działa ona autonomicznie. „Na tym właśnie polega jej źródłowa wolność. Bo «my» $\mathrm{i}$ «nasza wola» to jedno; a rozum stoi obok" ${ }^{36}$. Do tradycji woluntatystycznej zalicza Wolniewicz: św. Augustyna, Dunsa Szkota, Schopenhauera $^{37}$, Wittgensteina, Miłosza czy Conrada.

Intelektualizm etyczny twierdzi natomiast, że rozum dominuje nad wolą, co ma oznaczać, że rozum pobudza wolę do działania. Znane powiedzenie Kartezjusza: „Myślę, więc jestem”, zaliczyć należy do tradycji intelektualistycznej, w duchu woluntatyzmu powie się: „chcę, więc jestem”38.

\section{„Prawo względnego przyrostu szczęśliwości” Ehrenfelsa}

Wolniewicz akceptuje „prawo względnego przyrostu szczęśliwości” Christiana von Ehrenfelsa (1859-1932) opublikowane w 1887 r. Ma ono postać:

Każdy akt dążenia lub chcenia, pojawiając się, zwiększa stan szczęśliwości w porównaniu ze stanem, jaki wystąpiłby, gdyby ów akt się nie pojawi1 ${ }^{39}$.

Przez wzrost szczęśliwości trzeba zawsze rozumieć więcej przyjemności lub mniej bólu ${ }^{40}$.

35 B. Wolniewicz, Elzenberg o Miłoszu [1997], w: tegoż, Filozofia i wartości, t. II, WFiS UW, Warszawa 1998, s. 194-202.

36 B. Wolniewicz, Aksjomat Elzenberga, dz. cyt., s. 287.

37 J. Zubelewicz, Ostatnie rozmowy z Profesorem Bogusławem Wolniewiczem: wola a rozum wedtug Schopenhauera, „Edukacja Filozoficzna” 2017, nr 64, s. 245-250.

38 B. Wolniewicz, Aksjomat Elzenberga, dz. cyt., s. 287 oraz B. Wolniewicz, Polemika Kanta, dz. cyt., s. $145-146$.

39 Ch. von Ehrenfels, System der Werttheorie, Reisland, Leipzig 1897, Bd. 1: Allgemeine Werttheorie. Psychologie des Begehrens, s. 32, za: B. Wolniewicz, Hedonizm teoretyczny i prawo Ehrenfelsa, w: tegoż, Filozofia $i$ wartości, t. III, dz. cyt., s. 42.

40 Za: B. Wolniewicz, Hedonizm teoretyczny, dz. cyt., s. 44. 
Prawo to było przedmiotem szczegółowych analiz Wolniewicza i w rezultacie można by je zapisać w postaci:

(10) Człowiek zawsze dąży do tego, co jemu samemu w danej sytuacji jest ze wszystkich otwierających się w niej opcji najbardziej przyjemne albo najmniej przykre, po uwzględnieniu wysiłku związanego $\mathrm{z}$ tym dążeniem ${ }^{41}$.

Jest to zasada antropologicznego hedonizmu osobniczego (ze względu na cel i wysiłek). Wartość hedoniczna celu wraz z kosztami jego osiągnięcia to suma wartości hedonicznej samego celu i niedodatniej wartości hedonicznej wysiłku niezbędnego, by ów cel osiągnąc ${ }^{42}$. Tezę (10) wyraził Wolniewicz jeszcze w innej równoważnej postaci:

(10a) Każdy z konieczności dąży zawsze tylko do tego, co osobniczo jemu milsze (albo mniej niemiłe), po uwzględnieniu wysiłku związanego z tym dążeniem ${ }^{43}$.

Jest to antropologiczny hedonizm w wersji słabej (ze względu na cel i wysiłek). Gdy w tej zasadzie uwzględnimy tylko wartość hedoniczną celu, to otrzymamy zasadę antropologicznego hedonizmu osobniczego (ze względu na cel). Ma ona postać:

(10’) Człowiek zawsze dąży do tego, co jemu samemu w danej sytuacji jest ze wszystkich otwierających się w niej opcji najbardziej przyjemne albo najmniej przykre, bez względu na wysiłek związany z tym dążeniem.

Jest to zasada fałszywa. Przyjemność w zasadzie (10) rozumie się osobniczo. Jeżeli przyjmiemy, że ludzie posiadają tylko przyjemności gatunkowe, to otrzymamy zasadę antropologicznego hedonizmu gatunkowego (ze względu na cel i wysiłek):

${ }_{41}$ B. Wolniewicz, Hedonizm i obowiązek, dz. cyt., s. 110-111; tenże, Melioryzm Leibniza, dz. cyt., s. 296.

42 B. Wolniewicz, Hedonizm i obowiązek, dz. cyt., s. 111. Zob. również B. Wolniewicz, Motywy i motywacje, w: tegoż, Filozofia i wartości, t. IV, dz. cyt., s. 98-100.

43 B. Wolniewicz, Polemika Kanta, dz. cyt., s. 137 i 147-148. Do sformułowania Wolniewicza dopisano: „po uwzględnieniu wysiłku związanego z tym dążeniem”. 
(10”) Człowiek zawsze dąży do tego, co każdemu w danej sytuacji jest ze wszystkich otwierających się w niej opcji najbardziej przyjemne albo najmniej przykre, po uwzględnieniu wysiłku związanego $\mathrm{z}$ tym dążeniem ${ }^{44}$.

Jest to też teza fałszywa. Zasadę tę sformułował Wolniewicz także w następującej postaci:

(10a") Każdy z konieczności dąży zawsze tylko do tego, co gatunkowo każdemu milsze (albo mniej niemiłe), po uwzględnieniu wysiłku związanego $\mathrm{z}$ tym dążeniem ${ }^{45}$.

Jest to antropologiczny hedonizm w wersji mocnej (ze względu na cel i środki). Zasada ta, zwana zasadą hedonizmu, jest również fałszywa (podobnie jak zasada (10")). Wśród przyjemności osobniczych danego człowieka są bowiem oczywiście przyjemności gatunkowe, ale oprócz nich są jeszcze przyjemności typowe dla niego. Właśnie te typowe dla różnych osób przyjemności różnią ludzi. Każdy osobnik gatunku kieruje się bowiem swoją przyjemnością i w tym, co jemu przyjemne, objawia się jego charakter ${ }^{46}$.

Przyjemność - pisze Wolniewicz - lub raczej „przyjemniejszość” - o której w niej [zasadzie Ehrenfelsa - J.Z.] mowa, nie jest gatunkowa, lecz os ob nicza. Każdy osobnik gatunku powoduje się swoją przyjemnością: nie tylko w tym sensie „swoją", że przez niego odczuwaną, bo to rozumie się samo przez się; lecz i w tym, że może jest mu ona właściwa jedynie osobniczo, jak kolor oczu lub słuch muzyczny. Jedni jej doznają, drudzy nie; jednego cieszy, że może komuś pomóc, drugiego - gdy może mu podstawić nogę. U każdego osobnika znajdują się oczywiście pośród ogółu jego osobniczych przyjemności także wszystkie przyjemności gatunkowe - ale nie tylko te! Bo będą tam i takie, które u różnych osobników są różne. Charakter objawia się w tym, co komu przyjemne osobniczo; gatunkowo przyjemne jest wszystkim to samo ${ }^{47}$.

Problem poruszany w tezie (10) był, rzecz jasna, poruszany wcześniej przez wielu badaczy. Dla przykładu przytoczę wypowiedź Hobbesa: „Wszyscy bowiem

\footnotetext{
44 B. Wolniewicz, Hedonizm i obowiązek, dz. cyt., s. 131-132.

45 B. Wolniewicz, Polemika $z$ Kantem, dz. cyt., s. 137 i 147-148.

46 B. Wolniewicz, Hedonizm i obowiąek, dz. cyt., s. 133.

47 Tamże, s. 132-133.
} 
ludzie z konieczności rzeczy wybierają to, co im samym wydaje się dla nich najlepsze"48. Leibniz uważał, że

[...]jest rzeczą niemożliwą, cokolwiek by się mówiło, oderwać się od własnego dobra. [...] Nie można chcieć niczego, jak tylko tego, co się uważa za dobre; i w miarę, jak zdolność rozumienia jest rozwinięta, wybór woli jest lepszy ${ }^{49}$.

Oczywiście pozostaje tutaj otwarty m.in. problem rozumienia dobra. Ujęcie Leibniza był analizowane przez Wolniewicza ${ }^{50}$. Teza (10) ma mieć uniwersalny charakter. W szczególności stosuje się do działań i analiz ekonomicznych.

Wobec przedstawionej koncepcji można by zgłosić zarzut, że nie zawsze wartość hedoniczna wysiłku musi być niedodatnia, bo przecież są wysiłki przyjemne. Ale trzeba, według Wolniewicza, odróżnić wysiłek fizyczny od wysiłku woli. Ten pierwszy nie musi być przykry, ten drugi jest zawsze przykry ${ }^{51}$.

\section{Wspólnotowość człowieka}

W swoich analizach nad wspólnotą nawiązał Wolniewicz do analiz Ferdynanda Tönniesa (1855-1936) i jego dzieła Gemeinschaft und Gesellschaft z 1887 r. Tönnies wyodrębnia tam gromady ludzkie dwojakiego rodzaju: naturalne i sztuczne, i nazywa je odpowiednio wspólnotami i stowarzyszeniami ${ }^{52}$. Wyróżnikiem wspólnot jest wola spontaniczna (Wesenswille), wola płynąca z instynktu. Pierwowzorem jest miłość macierzyńska, czy szerzej: rodzinna. W stowarzyszeniu dominuje wola arbitralna (Kuerville), wola płynąca $\mathrm{z}$ rozsądku ${ }^{53}$. Swoje zainteresowania Wolniewicz koncentruje na wspólnotach. Kolejna jego teza ma postać:

(11) Ludzie w sposób samoistny tworzą trwałe, ekskluzywne wspólnoty duchowe ${ }^{54}$.

\footnotetext{
T. Hobbes, Elementy filozofii, t. 2, tłum. Cz. Znamierowski, PWN, Warszawa 1956, s. 285.

49 G.W. Leibniz, Nowe rozważania dotyczace rozumu ludzkiego, t. 1, tłum. i oprac. I. Dąbska, Warszawa 1955, odpowiednio s. 183 i 210. Cyt. za: B. Wolniewicz, Melioryzm Leibniza, dz. cyt., odpowiednio s. 295 i 296.

$50 \quad$ B. Wolniewicz, Melioryzm Leibniza, dz. cyt., s. 294-296.

51 B. Wolniewicz, Motywy i motywacje, dz. cyt., s. 99-100.

52 Z. Musiał, B. Wolniewicz, Ksenofobia i wspólnota [2003], w: tychże, Ksenofobia $i$ wspólnota, dz. cyt., s. 28.

54 Tamże, s. 31.
}

53 Tamże, 33. 
Ludzie odczuwają wobec siebie wzajem siły emocjonalne: sympatii lub antypatii. Tworzą się wśród ludzi różne więzi duchowe. Wstępne określenie wspólnoty duchowej podane przez Wolniewicza i Musiała brzmi następująco: to taka zbiorowość ludzka, którą łączy jakaś trwała więź duchowa ${ }^{55}$. Wspólnoty duchowe są trwałe, ekskluzywne, rozciągłe w czasie, samoistne. Ekskluzywność oznacza, że musi być podział na „my” i „oni”. Nie ma wspólnoty duchowej całej ludzkości: nie ma bowiem wtedy antropologicznego tła - nie ma ,innych”. Nie wyklucza to podejmowanie niektórych w miarę zgodnych działań przez wszystkie czy prawie wszystkie państwa świata. Wspólnoty obejmują żywych, umarłych i tych jeszcze nienarodzonych. Wykazują się troską o wychowanie w swoim duchu i tradycji. Intensywność tej troski to miara żywotności wspólnoty. W każdej wspólnocie występuje też pewien poziom ksenofobii. Rozwinięte określenie wspólnoty ma postać: „to taka zbiorowość ludzka, w której dla każdego jej członka suma jego więzi ad intra («do wewnątrz») przewyższa sumę jego więzi ad extra («na zewnątrz»)" ${ }^{\prime 56}$, gdzie przez więzi rozumie się siły emocjonalne, czyli siły sympatii i antypatii. Wspólnoty duchowe są nadbudowane nad wspólnotami społecznymi: dom nad rodziną, ojczyzna nad narodem, Kościół nad wiernymi, cywilizacja w aspekcie duchowym nad członkami tej cywilizacji. „Człowiek jest - jak pisał Ludwik Gumplowicz (1857-1909) - zwierzęciem stadnym"57. Zmaganie się to nieodłączna forma relacji między paralelnymi wspólnotami, dotyczy to głównie cywilizacji, religii i ojczyzn. W wyniku tego zmagania się powstają granice tych wspólnot, gdzie rezultat bilansu sumy sił przyciągania i odpychania daje opcję zerową.

(12) Świat, od strony duchowej, dzieli się na cywilizacje, sprzężone z odpowiednimi religiami. W cywilizacjach są ojczyzny, w ojczyznach domy.

\section{Organiczność języka}

Język można usytuować między rozumem człowieka a rzeczywistością. Z jednej strony jest on współrozciągły $\mathrm{z}$ naszym myśleniem, $\mathrm{z}$ drugiej zaś stanowi

Tamże, s. 30.

$56 \quad$ Tamże, s. 38.

57 L. Gumplowicz, Filozofia społeczna [1912], tłum. S. Posner, Nakładem Księgarni E. Wende i S-ka, Lwów [1918], s. 34. 
zwierciadło rzeczywistości, tzn. logiczna struktura języka odzwierciedla w jakiś sposób metafizyczną strukturę świata ${ }^{58}$. Wolniewicz rozróżnia dwa sposoby rozumienia języka. W ujęciu naturalistycznym (fabrykacyjnym) język to głównie środek komunikacji, w ujęciu antynaturalistycznym (emanacyjnym) - to część ludzkiej natury i przede wszystkim nośnik prawdy ${ }^{59}$. Zapiszmy to w postaci kolejnej tezy:

(13) Język jest częścią ludzkiej natury i przede wszystkim nośnikiem prawdy.

Wolniewicz uzupełnia tę tezę następującym komentarzem:

Tak pojęty język nie jest dziełem ludzkim, lecz emanacją wszechświata: nie jest czymś takim jak nóż i auto, lecz takim jak drzewo lub rzeka. Świat wydaje z siebie pewne medium, w którym sam odzwierciedla się jako prawda. My ludzie jesteśmy w tym wszystkim jedynie konstrukcją pomocniczą ${ }^{60}$.

W tym drugim ujęciu język stanowi, jak twierdzi za Wittgensteinem Wolniewicz, część ludzkiego organizmu. Jedna z tez (4.002) Traktatu ma postać: "Język potoczny stanowi część organizmu ludzkiego i jest nie mniej niż on skomplikowany"61.

Ulrich Schrade, na podstawie tekstów Wolniewicza, w taki oto sposób opisuje rozumienie języka w przedstawionych ujęciach:

Według koncepcji fabrykacyjnej język jest tworem czysto ludzkim powstałym z doskonalenia zwierzęcych kodów informacyjnych, służącym jako narzędzie komunikacji międzyludzkiej w walce o biologiczne przetrwanie. Język jest sprawą czysto umowną i dowolną - wszystko jest w nim dopuszczalne, byle tylko dobrze spełniał swe funkcje komunikacyjno-ekspresyjne. Natomiast według koncepcji emanacyjnej język jest koniecznym, narzuconym ludziom przez byt wytworem, w którym odzwierciedla się logiczna forma rzeczywistości. W strukturze logicznej języka zawarta jest pewna wiedza o świecie - prawda aprioryczna, która wymusza określony sposób myślenia o rzeczywistości ${ }^{62}$.

\footnotetext{
B. Wolniewicz, W stronę rozumu, dz. cyt., s. 123-124.

59 B. Wolniewicz, O pojęciu języka [1974], w: tegoż, Filozofia i wartości, t. II, dz. cyt., s. 81.

60 Tamże.

${ }_{61}$ L. Wittgenstein, Tractatus logico-philosophicus, tłum. B. Wolniewicz, PWN, Warszawa 1997, teza 4.002, s. 20, cyt. za: B. Wolniewicz, O pojęciu języka, dz. cyt., s. 82.

62 U. Schrade, M. Omyła, Bogusław Wolniewicz, „Edukacja Filozoficzna” 2001, nr 31, s. 198.
} 


\section{Organiczność religijnego poruszenia duszy}

Czy istnieje korzeń antropologiczny religii, a jeżeli tak, to co nim jest? Tym problemem zajął się Wolniewicz w 1992 r. w tekście O istocie religii ${ }^{63}$. Przez „korzeń" danego zjawiska rozumie on najbliższy warunek konieczny jego istnienia. Bliskość ta ma odpowiadać bliskości „najbliższego rodzaju” w definicji ${ }^{64}$. Równocześnie korzeń ten ma odnosić się do natury ludzkiej, ma być jakimś faktem antropologicznym. Teza końcowa, do której dochodzi Wolniewicz, brzmi następująco (jest to teza $F$ ):

(14) Korzeniem antropologicznym religii jest pewność śmierci ${ }^{65}$.

Teza ta jest uwieńczeniem pewnego ciągu wcześniejszych tez:

- teza A - Korzeniem religii jest śmierć;

- teza B - Gdyby nie było śmierci, to nie byłoby religii;

- teza C - Człowiek jest to połączenie rozumu ze śmiercią (św. Bernard z Clairvaux);

- teza D - Religijne poruszenie duszy jest to poruszenie jej przez śmierć;

- teza E - Korzeniem religii jest pewność śmierci, korzeniem magii jest niepewność losu ${ }^{66}$.

W wykładzie z dnia 10.11.2013 r. formułuje Wolniewicz swą tezę w następującej postaci:

(14a) Korzeniem religii jest świadomość człowieka, że musi umrzeć.

Są tam też pewne stwierdzenia o relacjach między religią a moralnością: moralność w swoim korzeniu należy uznać za niezależną od religii, a sumienie to korzeń moralności ${ }^{67}$.

63 B. Wolniewicz, O istocie religii [1992], w: tegoż, Filozofia $i$ wartości. Rozprawy $i$ wypowiedzi, dz. cyt., s. 160-198.

64 Tamże, s. 185.

65 Tamże, s. 187.

66 Tamże, odp. na ss. 168, 170, 172, 175 i 183.

67 B. Wolniewicz, Wrodzone a nabyte, Głos racjonalny, wykład 8. z 10.11.2013, URL: https://www. youtube.com/watch?v=7Jcags3BdXQ, początek nagrania, dostęp: 25.07.2019. 


\section{Teoria walki}

Nie ulega wątpliwości, że w życiu społecznym istnieje i walka, i współpraca. Co jednak wyraża to życie głębiej: walka czy współpraca? Wolniewicz opowiada się za pierwszym rozwiązaniem. Jest więc - to określenie pochodzi ode mnie - zwolennikiem teorii walki, a nie teorii współpracy. W związku z tym głosi następującą tezę:

(15) Walka o władzę i wpływy jest jedną z cech natury człowieka.

Chyba najwyraźniej teza ta występuje w tekście $O$ tzw. prawach człowieka (2002). Wolniewicz pisze tam:

A walka ta [walka o władzę i wpływy] nie ustaje nigdy, jak oddech i puls póki żyjemy. Jest bowiem emanacją natury ludzkiej, wygasić jej się nie da; można ją najwyżej nieco ucywilizować, złagodzić jej formy - jak np. zrobiono to $w$ boksie. W sumie miał rację Hobbes, jakkolwiek niemiłe by to nam było ${ }^{68}$.

Być może omawiana cecha została najwcześniej przedstawiona w tekście $C y$ wilizacja techniczna $(1982)^{69}$ :

Świat nie rządzi się rozumem, lecz namiętnościami, a najpotężniejszym motorem postępu technicznego były dotąd zawsze zbrojenia.

Cechą jednostek i zbiorowości ludzkich jest nieustanna walka między sobą, nieustanna wzajemna konkurencja. Toczy się ona przede wszystkim w sferze ekonomicznej, ale w swej najbardziej drastycznej formie przybiera właśnie postać walki zbrojnej. Konieczności tej walki zmuszają człowieka do stałego, maksymalnego wysiłku technicznego, by w tej najkrytyczniejszej dziedzinie nie dać się prześcignąć innym.

W roku 1989 Wolniewicz pisał, że:

[...] życie ludzkie nie jest radosną przygodą, tylko cierpieniem i walką. I że nigdy nie będzie inne, bo taka jest natura ludzka, a natura się nie zmienia ${ }^{70}$.

68 B. Wolniewicz, O tzw. prawach człowieka [2002], w: Z. Musiał, B. Wolniewicz, Ksenofobia i wspólnota, dz. cyt., s. 92 .

69 B. Wolniewicz, Cywilizacja techniczna [1982], w: tegoż, Filozofia i wartości. Rozprawy i wypowiedzi, dz. cyt., s. 236.

70 B. Wolniewicz, Z antropologii Schopenhaeura [1989], w: tegoż, Filozofia i wartości. Rozprawy i wypowiedzi, dz. cyt., s. 101. 
Przytacza także z aprobatą słowa Hioba: „Bojowaniem jest żywot człowieczy na ziemi" "11. Walka o władzę i wpływy występuje zawsze, może jednak czasem zmienić swoją arenę, jak np. w przypadku walki politycznej. Została ona w części przesunięta do sfery sądownictwa, które w ten sposób się upolityczniło ${ }^{72}$.

\section{Genetyczne uwarunkowanie percepcji natury ludzkiej}

Wróćmy jeszcze do wątku z punktu 2.1. tego tekstu. W opracowanym schemacie motywacji etycznej Wolniewicz wyodrębnia dwa zespoły dyspozycji: inteligencję (ogół dyspozycji intelektualnych) i usposobienie (ogół dyspozycji emocjonalnych $)^{73}$. W ramach inteligencji wyróżnia rozum teoretyczny i rozum praktyczny. Ten pierwszy charakteryzuje się zdolnością odróżniania prawdy od fałszu, ten drugi - dobra od zła. Zdolność pierwsza w odniesieniu do percepcji niektórych cech natury ludzkiej jest, według Wolniewicza, ograniczona. Percepcje te są uwarunkowane genetycznie i mogą być prawdziwe lub fałszywe. Zarazem ludziom towarzyszy przekonanie, że są one prawdziwe. Wolniewicz uważa, że percepcje te, przynajmniej niektóre, nie są poglądami, lecz rysami lub typami osobowości w sferze poznawczej. Można by chyba obrazowo powiedzieć tak: rozum teoretyczny może nas skutecznie oszukiwać i nie jesteśmy w stanie tego stwierdzić. Kolejna teza ma postać:

(16) Percepcje (prawdziwe lub fałszywe) niektórych cech natury ludzkiej odczuwane są jako prawdziwe. Nie są one poglądami, lecz typami osobowości uwarunkowanymi genetycznie.

Tę zasadę ukazał Wolniewicz przy percepcji np. takich cech natury ludzkiej jak: nonmelioryzm czy melioryzm, woluntaryzm czy intelektualizm etyczny, tychizm czy antropizm. Przypuszczam, że ta prawidłowość odnosi się też do innych cech natury ludzkiej, np. teorii walki czy teorii współpracy.

\footnotetext{
71 B. Wolniewicz, Wstęp, w: tegoż, Filozofia i wartości, t. III, dz. cyt., s. X.

72 Patrz np. B. Wolniewicz, Sądownicza erozja swobód demokratycznych (przyczynek do filozofii prawa karnego) [2005/2006], w: tegoż, Filozofia $i$ wartości, t. IV, Wydawnictwa UW, Warszawa 2016, s. 195-202. Przedruk z: „Annales Universitatis Mariae Curie-Skłodowska. Sectio G, Ius” 2005/2006, t. 52/53, s. 185-190.

73 B. Wolniewicz, Hedonizm i obowiązek, dz. cyt., s. 119.
} 


\section{Uwagi}

$\mathrm{Z}$ aprobatą odnoszę się do tez antropologii filozoficznej Wolniewicza. Do przedstawionych już uwag dołączę jeszcze kilka komentarzy.

\section{Egalitarny czy elitarny charakter sumienia biernego (rozumu praktycznego)}

Rozum teoretyczny, według Wolniewicza, cechuje się zdolnością do odróżniania prawdy od fałszu, rozum praktyczny (sumienie bierne) - zdolnością do odróżniania dobra od zła. $Z$ powyższych rozważań wynika, że rozum teoretyczny nie zawsze odróżnia prawdę od fałszu. Czasami fałsz uznaje za prawdę. Rozum teoretyczny nie ma charakteru egalitarnego. A jak z rozumem praktycznym? Czy on zawsze odróżnia dobro od zła? Wolniewicz odpowiada twierdząco. A może rozum praktyczny, tak jak rozum teoretyczny, czasami nas „oszukuje”?

\section{Religijne poruszenie duszy a dyspozycje emocjonalne}

W schemacie motywacji etycznej Wolniewicz wyróżnia dyspozycje intelektualne (rozum teoretyczny i rozum praktyczny) oraz dyspozycje emocjonalne (czułość podmiotu na własny interes oraz czułość podmiotu na dobro i zło) ${ }^{74}$. Gdzie w tym schemacie mieści się religijne poruszenie duszy? Czy mieści się ono w sumieniu czynnym (czułość podmiotu na dobro i zło)? Czy może należałoby rozszerzyć dyspozycje emocjonalne jeszcze o te nadbudowane nad religią? Na ten wątek zwraca uwagę Paweł Okołowski w tekście Myśl Wolniewicza. Zrąb systemu ${ }^{75}$.

\section{Rozumienie przeznaczenia}

Wolniewicz wyodrębnia trzy czynniki przeznaczenia: genotyp, wspólnota, w której się rodzimy, i duch czasu, w którym się rodzimy. Można chyba wyróżnić jeszcze dwa czynniki, niezależne od nas i wpływające na nasze życie.

\footnotetext{
74 Analiza Wolniewiczowskiego schematu motywacji etycznej, w: P. Okołowski, Prawo- i lewoskrętność jako bieguny stosunku do losu (przyczynek do „nowoczesnego tradycjonalizmu”), „Sensus Historiae. Studia interdyscyplinarne" 2018, t. 23, nr 4, podrozdz. Kaskada wolicjonalna, s. $187-189$.

75 P. Okołowski, Myśl Wolniewicza. Zrąb systemu, „Przegląd Filozoficzny” 2018, nr 3, s. 262.
} 
Uważam, że w przeznaczeniu należałoby wyodrębnić czynnik czwarty: stan organiczny matki danego człowieka w trakcie ciąży ${ }^{76}$. Jej organizm może bowiem różnie reagować na dziecko. Być może czynnik ten podciągnąłby Wolniewicz pod genotyp, może pod przypadek, a być może zgodziłby się z tą korektą.

Wreszcie można by wyodrębnić czynnik piąty: przeżyte doświadczenia życiowe. Udział w takich doświadczeniach wyklucza zaistnienie pewnych przyszłych sytuacji. Można by to powiedzieć jeszcze inaczej: przeszłe przypadki wchodzą w skład przeznaczenia (przypadki stają się przeznaczeniem). Ta zależność przemawia też za tezą Wolniewicza, że przypadek ma większą rangę niż przeznaczenie.

\section{Zastąpienie terminu „deontysta racjonalistyczny” terminem „deontysta antropiczny”}

Opozycją „deontysta racjonalistyczny” - „deontysta tychiczny” zajmował się Wolniewicz w tekście Elzenberg o Miłoszu (1997) ${ }^{77}$, a potem w pracy Polemika Kanta $z$ hedonizmem (2016) ${ }^{78}$. I właściwie dopiero wtedy w tym drugim opracowaniu terminy te pojawiły się explicite. Deontysta racjonalistyczny przyjmuje, że obowiązek da się racjonalnie uzasadnić, np. imperatywem kategorycznym w przypadku Kanta czy zasadą „maksymizacji dobra” w przypadku Elzenberga. Równocześnie towarzyszy temu wiara, że racjonalność tych zasad może zmusić nas do odczucia obowiązku i spełnienia go. Tak sądził - zauważa Wolniewicz - Elzenberg w 1940 r. Potem jego wiara w racjonalne uzasadnienie obowiązku wyraźnie przygasła. W 1962 r. w tekście Brutus i przekleństwo cnoty pisał on:

Nie myślcie [...], by jakiekolwiek „racje” etyczne [...] mogły wam, jako motor działania, zastąpić żywioł, namiętność, przyrodzoną ekspansywność zdobywczej, agresywnej osobowości ${ }^{79}$.

Zwolennicy deontyzmu tychicznego - według Wolniewicza - przyjmują, że idea obowiązku może być sprawcza tylko wtedy, gdy świadomości obowiązku

\footnotetext{
76 Taką propozycję zgłosił Kamil Zubelewicz. Bodajże w r. 2015 zaproponował on zastąpienie terminu „przeznaczenie” terminem „naznaczenie”, ale prof. Wolniewicz nie zaakceptował tej zamiany. Niemniej jednak nasze przeznaczenie naznacza każdego $\mathrm{z}$ nas.

77 B. Wolniewicz, Elzenberg o Miłoszu, dz. cyt., s. 194-202.

78 B. Wolniewicz, Polemika Kanta, dz. cyt., s. 145.

79 H. Elzenberg, Brutus i przekleństwo cnoty [1962], w: tegoż, Próby kontaktu. Eseje i studia krytyczne, Znak, Kraków 1966, s. 190, cyt. za: B. Wolniewicz, Polemika Kanta, dz. cyt., s. 146.
} 
towarzyszy wola zrealizowania go. Ta wola leży poza naszym rozumem. Dokładniej, dotyczy to tylko woli pierwotnej, nabudowana na niej wola wtórna jest już kierowana przez rozum. Poczucie obowiązku oparte jest na woli pierwotnej. Do grona przedstawicieli deontyzmu tychicznego zalicza Wolniewicz m.in. Conrada i Miłosza.

W rozmowie z Prof. Wolniewiczem w r. 2016 powiedziałem, że termin „deontyzm racjonalistyczny” można by zastąpić terminem „deontyzm antropiczny”. Prof. Wolniewicz zaakceptował tę zamianę. Spór i dbałość o nazewnictwo nie musi być tylko drobną sprawą terminologiczną:

Wielkie to jednak złudzenie - pisał Elzenberg - przypuszczać, że walki o słowa - to tylko walki o słowa. Walki o słowa - to walki o możność oszukania bliźniego, o palladia, o talizmany. Fetyszem jest i termin „nauka” [...]. Rzeczą główną jest różnica w szacunku ${ }^{80}$.

Równie dobrze można by w miejsce terminu „nauka” wstawić termin „racjonalistyczny".

W czasach Oświecenia wielu filozofów i reformatorów głosiło pochwałę rozumu i podawało różne rozumne według nich rozwiązania społeczne. W opinii Alexisa de Tocqueville’a głosili oni nie tyle pochwałę rozumu i racjonalizmu, ile pochwałę swojego rozumu i swojego racjonalizmu, a to oczywiście nie to samo. Przytoczmy fragment wspaniałego przypisu 14. Dawnego ustroju i rewolucji:

Powiedziano, że znamieniem filozofii XVIII wieku było coś na kształt adoracji ludzkiego rozumu, bezgraniczna ufność w jego wszechpotęgę mogącą dowolnie przekształcać prawa, instytucje i obyczaje. Powiedzmy sobie szczerze: $\mathrm{w}$ istocie niektórzy z tych filozofów wielbili nie tyle rozum ludzki, co swój własny. Nikt nigdy nie okazał takiego jak oni braku zaufania do powszechnego rozsądku. Mógłbym tu wymienić kilku, którzy niemal tak samo pogardzali tłumem jak Panem Bogiem. Boga traktowali z pychą rywali, a tłum z pychą parweniuszy. Rzeczywiste i pełne szacunku podporządkowanie się woli większości było im tak samo obce, jak poddanie się woli bożej. Od tamtej pory niemal wszyscy rewolucjoniści łączyli w sobie obie te cechy ${ }^{81}$.

80 H. Elzenberg, O „wąskim” pojmowaniu nauki, „Wiadomości Literackie” 1926, nr 41, s. 2.

${ }^{81}$ A. de Tocqueville, Dawny ustrój i rewolucja [1856], tłum. A. Wolska, Czytelnik, Warszawa 1970, s. 320 . 
O Kancie i Elzenbergu powiemy więc, że byli deontystami antropicznymi, a nie racjonalistycznymi.

\section{O teorii walki}

Wolniewicz słusznie zwraca uwagę na głębszą rolę walki o władzę i wpływy niż współpracy w życiu człowieka. Powołuje się nawet na Hobbesa: „W sumie miał rację Hobbes, jakkolwiek niemiłe by to nam było" ${ }^{22}$. Znane powiedzenie Hobbesa ma postać: „człowiek człowiekowi wilkiem”. Nasuwają się tu różne pytania. Jak to powiedzenie odnieść do rzeczywistości? Gdzie w świecie trwa walka o największym natężeniu? Jaka jest, jeżeli w ogóle jest, gradacja walk? W duchu filozofii Gumplowicza można by podać taką interpretację: „państwo państwu wilkiem”.

Ja natomiast skłaniam się do innego ujęcia interpretacyjnego: „strefa wpływów strefie wpływów wilkiem". Świat, od strony politycznej, dzieli się na strefy wpływów i strefy buforowe. W strefie wpływów jest centrum hegemoniczne (w zasadzie jedno państwo hegemoniczne wraz z bankowością i korporacjami) i państwa zależne. Największe nasilenia walk są między strefami wpływów. W ramach stref wpływów są zmagania między centrum hegemonicznym a państwami zależnymi. Centrum hegemoniczne stara się w większym stopniu podporządkować państwa zależne, a one z kolei usiłują uzyskać większą niezależność dla siebie.

Ekonomia funkcjonuje zawsze w ramach politycznych. To polityka, nie ekonomia, ustala cła, subwencje, podatki, zwolnienia $\mathrm{z}$ ceł, rezygnację $\mathrm{z}$ subwencji, zwolnienie od podatków, proponuje czy wręcz wymusza zapożyczanie się itd. To m.in. poprzez udzielanie kredytów największe mocarstwa świata i sprzężone z nimi banki (w tym w szczególności amerykańsko-izraelskie centrum hegemoniczne) podporządkowują inne państwa.

82 B. Wolniewicz, O tzw. prawach człowieka [2002], w: B. Wolniewicz, Z. Musiał, Ksenofobia i wspólnota. Przyczynek do filozofii człowieka, dz. cyt., s. 92. 


\section{Zakończenie}

Jaka jest natura człowieka? Tym problemem interesował się Profesor Wolniewicz niemal przez całe życie. Można powiedzieć więcej: tajemnicza natura ludzka fascynowała go i zarazem pociągała do bliższego zainteresowania się nią. Do aksjologii miał trochę sceptyczne podejście.

Antropologię Wolniewicza cechuje przede wszystkim radykalny natywizm oraz m.in. nonmelioryzm, tychizm, woluntatyzm, teoria walki, organiczność języka, organiczność religii, wspólnotowość człowieka, predestynacja sumienia.

Prawdziwe i fałszywe percepcje niektórych cech natury człowieka są uwarunkowane genetycznie. Są one wyrazem pewnych typów osobowości w sferze poznawczej. Percepcjom tym towarzyszy przekonanie ludzi o ich prawdziwości.

\section{Bibliografia}

von Ehrenfels Ch., System der Werttheorie, Bd. 1: Allgemeine Werttheorie. Psychologie des Begehrens, Reisland, Leipzig 1897.

Elzenberg H., Brutus i przekleństwo cnoty [1962], w: tegoż, Próby kontaktu. Eseje i studia krytyczne, Znak, Kraków 1966, s. 188-192.

Elzenberg H., O „wąskim” pojmowaniu nauki, „Wiadomości Literackie” 1926, nr 41, s. 2.

Gumplowicz L., Filozofia społeczna [1912], tłum. S. Posner, Nakładem Księgarni E. Wende i S-ka, Lwów [1918].

Hobbes T., Elementy filozofii, t. 2, tłum. Cz. Znamierowski, PWN, Warszawa 1956.

Hume D., A Treatise of Human Nature, edited with an analytical index, by L.A. Selby-Bigge, Oxford 1869.

Leibniz G. W., Nowe rozważania dotyczace rozumu ludzkiego, t. 1, tłum. i oprac.

I. Dąbska, PWN, Warszawa 1955.

Musiał Z., Wolniewicz B., Ksenofobia i wspólnota [2003], w: tychże, Ksenofobia i wspólnota. Przyczynek do filozofii człowieka, s. 7-89.

MusiałZ., Wolniewicz B., Ksenofobia i wspólnota. Przyczynek do filozofii człowieka, wyd. 2 poszerzone, Wydawnictwo Antyk - Marcin Dybowski, Komorów 2010. 
Musiał Z., Wolniewicz B., Wstęp, w: tychże, Ksenofobia i wspólnota. Przyczynek do filozofii człowieka, s. 7-14.

Okołowski P., Myśl Wolniewicza. Zrąb systemu, „Przegląd Filozoficzny” 2018, nr 3, s. 269-266, URL: http://journals.pan.pl/pfns/125756, dostęp: 9.03.2019.

Okołowski P., Prawo- i lewoskrętność jako bieguny stosunku do losu (przyczynek do „nowoczesnego tradycjonalizmu”), „Sensus Historiae. Studia Interdyscyplinarne” 2018, t. 23, nr 4, s. 181-196, URL: http://www.sensushistoriae.epigram. eu/index.php/czasopismo/article/view/474/481, dostęp: 25.07.2019.

Schrade U., Omyła M., Bogusław Wolniewicz, „Edukacja Filozoficzna” 2001, nr 31, s. 190-218.

Wittgenstein L., Tractatus logico-philosophicus, tłum. B. Wolniewicz, PWN, Warszawa 1997.

Wolniewicz B., Aksjomat Elzenberga, „Przegląd Filozoficzny” 2017, nr 4(104), s. 277-288, URL: http://journals.pan.pl/Content/106455/PDF/P.Filoz.\%20 4-17\%2020-B.Wolniewicz.pdf, dostęp: 9.03.2019. Wcześniejsza wersja dźwiękowa Wola czy rozum: aksjomat Elzenberga.

Wolniewicz B., Cywilizacja techniczna [1982], w: tegoż, Filozofia i wartości. Rozprawy $i$ wypowiedzi, s. 235-236.

Wolniewicz B., Elzenberg o Miłoszu [1997], w: tegoż, Filozofia $i$ wartości, t. II, WFiS UW, Warszawa 1998, s. 194-202.

Wolniewicz B., Filozofia i wartości, t. II, WFiS UW, Warszawa 1998 (wyd. 2: Wyd. UW, 2018).

Wolniewicz B., Filozofia $i$ wartości, t. III, WFiS UW, Warszawa 2003 (wyd. 2: Wyd. UW, 2018).

Wolniewicz B., Filozofia $i$ wartości, t. IV, Wyd. UW, Warszawa 2016 (dodruk: 2018).

Wolniewicz B., Filozofia i wartości. Rozprawy i wypowiedzi, WFiS UW, Warszawa 1993 (dodruk: 1998; wyd. 2: Wyd. UW, 2019).

Wolniewicz B., Hedonizm i obowiązek [2006/2007], w: tegoż, Filozofia i wartości, t. IV, s. 103-135.

Wolniewicz B., Hedonizm teoretyczny $i$ prawo Ehrenfelsa, w: tegoż, Filozofia $i$ wartości, t. III, s. 19-62.

Wolniewicz B., Melioryzm Leibniza, „Przegląd Filozoficzny” 2016, nr 4(100), s. 293-303, URL: http://journals.pan.pl/Content/100471/PDF/P.Fil.\%20 4-16\%2019-B.Wolniewicz.pdf, dostęp: 9.03.2019. Wcześniejsza wersja dźwiękowa Melioryzm Leibniza. 
Wolniewicz B., Melioryzm Leibniza, Głos racjonalny, wykład 82. z 7.06.2016, URL: https://www.youtube.com/watch?v=tp_q_oLW66o, dostęp: 11.08.2019. Wolniewicz B., Motywy i motywacje [2005], w: tegoż, Filozofia $i$ wartości, t. IV, s. 87-102.

Wolniewicz B., Naczelne wartości naukowego pogladu na świat [1980], w: tegoż, Filozofia $i$ wartości. Rozprawy i wypowiedzi, WFiS UW, Warszawa 1993, s. 62-68.

Wolniewicz B., O idei losu [2010], w: tegoż, Filozofia i wartości, t. IV, s. 247-259.

Wolniewicz B., O istocie religii [1992], w: tegoż, Filozofia i wartości. Rozprawy i wypowiedzi, s. 160-198.

Wolniewicz B., O pojęciu języka [1974], w: tegoż, Filozofia i wartości, t. IV, s. 79-83.

Wolniewicz B., O tzw. bioetyce [2001], w: tegoż, Filozofia $i$ wartości, t. III, s. 149-164.

Wolniewicz B., O tzw. prawach człowieka [2002], w: B. Wolniewicz, Z. Musiał, Ksenofobia i wspólnota. Przyczynek do filozofii człowieka, s. 91-101.

Wolniewicz B., Polemika Kanta z hedonizmem [2016], „Edukacja Filozoficzna” 2016, Nr specjalny, s. 83-93, URL: http://www.edukacja-filozoficzna.uw.edu. pl/index_pliki/efspec/09.\%20Wolniewicz.pdf, dostęp: 22.12.2018, przedruk w: tegoż, Filozofia $i$ wartości, t. IV, s. 137-148.

Wolniewicz B., Sądownicza erozja swobód demokratycznych (przyczynek do filozofii prawa karnego) [2005/2006], w: tegoż, Filozofia $i$ wartości, t. IV, Wydawnictwa UW, Warszawa 2016, s. 195-202. Przedruk z: „Annales Universitatis Mariae Curie-Skłodowska. Sectio G, Ius” 2005/2006, t. 52/53, s. 185-190, URL: http://dlibra.umcs.lublin.pl/dlibra/plain-content?id=4895, dostęp: 1.08.2019.

Wolniewicz B., Wola czy rozum: aksjomat Elzenberga, Głos racjonalny, wykład 100. z 13.06.2017, URL: https://www.youtube.com/watch?v=c1XWLPJLcUY, dostęp: 11.08.2019.

Wolniewicz B., Wrodzone a nabyte, Głos racjonalny, wykład 8. z 10.11.2013, URL: https://www.youtube.com/watch?v=7Jcags3BdXQ, dostęp: 25.07.2019.

Wolniewicz B., Wstęp, w: tegoż, Filozofia $i$ wartości, t. III, s. VII-XI.

Wolniewicz B., Wykład o krzywej życia, w: tegoż, W stronę rozumu, kompozycja tekstu J. Faliński, D. Dywańska, WEMA, Warszawa 2015, s. 140-145.

Wolniewicz B., Z antropologii Schopenhaeura [1989], w: tegoż, Filozofia i wartości. Rozprawy i wypowiedzi, s. 101-119.

Wolniewicz B., Z pedagogiki ogólnej, w: Dydaktyka szkoły wyższej: wybrane zagadnienia, red. U. Schrade, OW PW, Warszawa 2010, s. 9-34. 
Zubelewicz J., Cechy języka propagandy realnego socjalizmu, w: Skłonność metafizyczna. Bogusławowi Wolniewiczowi w darze, red. M. Omyła, WFiS UW, Warszawa 1997, s. 373-388.

Zubelewicz J., Ambiwalentna czy pozytywna rola psychologii wychowawczej i psychoterapii?, w: tegoż, Dwie filozofie edukacji: aksjocentryzm i pajdocentryzm, OW PW, Warszawa 2003, s. 70-75.

Zubelewicz J., Ostatnie rozmowy z Profesorem Bogusławem Wolniewiczem: wola a rozum według Schopenhauera, „Edukacja Filozoficzna” 2017, nr 64, s. 245-250, URL: http://www.edukacjafilozoficzna.uw.edu.pl/?page_id=160, dostęp: 9.03.2019.

Zubelewicz J., Przyczyny przemocy uczniów wobec nauczycieli. Pedagogika akademicka a pedagogika Johanna F. Herbarta i Bogusława Wolniewicza, w: Wychowanie i ksztatcenie $w$ systemach politycznych, red. E. Anhalt, D. Stępkowski, Wydawnictwo Salezjańskie, WNP UKSW, Warszawa 2012, s. 185-211.

\section{Streszczenie}

Podstawową cechą antropologii filozoficznej Wolniewicza jest natywizm radykalny. Człowiek zaczyna się w chwili poczęcia, czyli od powstania zygoty. W tym momencie powstają in potentia wszystkie jego główne cechy, te, które go determinują i określają jego tożsamość, jak np.: ekspansja życiowa i sprzężona z nią dynamika, charakter, inteligencja, temperament, sumienie, religijne poruszenie duszy, język, wspólnotowość, słuch muzyczny, płeć, grupa krwi, prawo- lub leworęczność, różne cechy fizyczne (np. wzrost, kolor oczu, kolor włosów, uroda) oraz percepcja niektórych cech natury ludzkiej. Antropologię filozoficzną Wolniewicza cechuje m.in.: radykalny natywizm, nonmelioryzm, tychizm, woluntatyzm, teoria walki, organiczność języka, organiczność religii, wspólnotowość człowie$\mathrm{ka}$, predestynacja sumienia.

Słowa kluczowe: antropologia filozoficzna, natywizm radykalny, tychizm, nonmelioryzm, woluntatyzm, sumienie 


\section{Summary}

\section{Philosophical Anthropology of Bogusław Wolniewicz}

The basic feature of Wolniewicz's philosophical anthropology is radical nativism. A man comes into being at their conception, that is, from the creation of a zygote. In potentia, all their main features, which determine them and define their identity, arise at this moment. They include: life expansion and its associated dynamics, character, intelligence, temperament, conscience, religious movement of the soul, language, sense of community, musical hearing, sex, blood type, right- or left-handedness, various physical characteristics (e.g. height, eye colour, hair colour, beauty), perception of some features of human nature, etc. Philosophical anthropology according to Wolniewicz is characterized, among others, by radical nativism, non-meliorism, tychism, voluntarism, organic nature of language, organic nature of religion, human sense of community, conscience predestination.

Key words: philosophical anthropology, radical nativism, tychism, non-meliorism, voluntarism, conscience 